\title{
Developing Intercultural Competence Awareness in Language Classrooms: A View from FL Teachers
}

\author{
Muh. Arif (Corresponding Author) \\ muharif@iaingorontalo.ac.id \\ IAIN Sultan Amai Gorontalo, Indonesia \\ Harni Jusuf \\ harnijusuf@iaingorontalo.ac.id \\ IAIN Sultan Amai Gorontalo, Indonesia
}

\begin{abstract}
Language and culture are now considered interwoven, as culture becomes an integral part of learning a foreign language. This study aims to ascertain FL lecturers' perspectives on intercultural education and classroom procedures, including instructional materials, classroom activities, assessment, and the role of teachers in fostering intercultural awareness. Six lecturers were surveyed in this study. The six lecturers include three Arabic language education lecturers and three English language education lecturers with roughly five years of teaching experience. The data collection instrument is an interview guideline. The findings indicated that instructors acknowledged the importance of integrating culture into FL classrooms via various strategies and methods. Their statements include the following: they are frequently compelled to keep to textbook activities and activities previously prepared for the textbook since they have little time in class to address cultural concerns due to the syllabi's high expectations.
\end{abstract}

Keywords: Intercultural competence; awareness; language classroom.

\section{A. INTRODUCTION}

It is possible to characterize as intercultural competence the interactions that take place between teachers and students during the language acquisition process in the classroom. Cultural background, age, ethnicity, socioeconomic status, religious belief system, and even educational degree are all factors that contribute to this (Jackson, 2019; Mirzaei \& Forouzandeh, 2013). Differential findings across various circumstances send a message that disparities are commonplace and that everyone should be aware of them. Not only that, but the process of interaction between students in the classroom, particularly when students from a variety of backgrounds congregate in the same class, may be considered a component of intercultural competency. 
Among the many reasons for this, recent research has reinforced the requirement and importance of developing the global perspectives and intercultural awareness of foreign language teachers (Róg et al., 2020; Wyant et al., 2019), among other things. In short, fostering intercultural competency in the classroom should be an important aspect of all language education, regardless of the type of language education being provided. Some of the most well-known and commonly accepted models of intercultural learning in FL education have been proposed by Bennett (2009) and Byram (2020), who acknowledge the importance of fostering intercultural discourse between societies in order to improve learning outcomes.

As a process of being more aware of and having a greater understanding of one's own culture as well as other cultures all over the world, intercultural awareness can be thought of as a way of life (Burden et al., 2013; Hashemian \& Farhang-Ju, 2020; Mirzaei \& Forouzandeh, 2013; Sevilla-Pavón, 2019; Vuksanovic, 2018). Its primary goal is to promote greater international and cross-cultural understanding and cooperation (Maharaja, 2018; Róg et al., 2020; Wolff \& Borzikowsky, 2018). Intercultural awareness is a collection of attitudes and skills that can be considered and better thought of as competence in and of itself (Ferreira-Lopes et al., 2018; Lieberman \& Gamst, 2015; Shadiev et al., 2020; Wang, 2020), according to (Gómez-Parra, 2020; King et al., 2013). These are some examples: The skills of (a) observing, (b) identifying and recording, (c) comparing and contrasting, (d) negotiating meaning, (e) dealing with or tolerating ambiguity, (f) effectively interpreting messages, (g) limiting the possibility of misinterpretation, (h) defending one's own point of view while acknowledging the legitimacy of others, and (I) accepting difference are all required.

The essence of actual classroom teaching practice in grasping the idea of culture and its reciprocal link with language is becoming increasingly apparent (Barnatt et al., 2020; Behrnd \& Porzelt, 2012; Holmes \& O’Neill, 2012; Pinto, 2018). However, further investigation is demanded to define the extent to which FL teachers emphasize culture in their classrooms and the methods by which they do so. These variables combined give the impetus for this study, which sought to determine whether or not language teachers are aware of how, when, and to what extent they use culture in their language sessions to improve student learning. 


\section{B. RESEARCH METHOD}

A deeper insight into the views of language teachers on the concept of culture and how they shape their classroom practices to develop appropriate intercultural competencies is the main object of study in this research. The research team invited six language lecturers to obtain these data, consisting of three Arabic language lecturers and three other English language lecturers. The six lecturers were then coded with AL 1 to 3 for Arabic Language Education Lecturers and EL 1 to 3 for English Language Education lecturers. The six volunteer lecturers were asked to provide an overview of their views on intercultural competence in foreign language learning in their classrooms so far.

The interview guide in this study asked the following questions:

1. How do Arabic and English lecturers define Culture in the practice of language learning in the classroom?

2. How important is the integration of cultural knowledge in language learning in the classroom?

3. What methods and techniques are suitable for teaching language classes with diverse backgrounds?

4. What materials or topics are suitable to be taught for these diverse language classes?

5. How do lecturers increase intercultural awareness in their students?

6. Do the reference books used in teaching include intercultural competence so far?

7. Is there a reason for lecturers not to teach intercultural competence in language learning in today's class?

8. How have students reacted so far in understanding culture in the context of the language material being taught?

These questions were asked face to face to the lecturers who volunteered in this research. The lecturer's answer is directly written on the research team's paper. The research data will be analyzed using content analysis. Content analysis is a research technique that allows for examining specific words or significant concepts included within texts (Ihm, 2020; Lustig, Myron W, 2010). The relationships and meanings between these words or ideas were studied using this technique, and probable inferences were drawn from the investigation. The text was divided into categories, and then 
linguistic components such as words, word phrases, sentences, and themes were extracted and studied from the text to carry out the content analysis technique (Ridder et al., 2014).

\section{FINDINGS AND DISCUSSION}

\section{Findings}

Definition of Culture according to Arabic and English teaching lecturers in teaching language in the classroom.

This question 1-2 aims to explore culture according to the Lecturer of Arabic Language Education and English Education. Lecturers are asked to write down their concept of culture and practice in language learning that has been done so far.

Table 1. Concept of Culture

Concept of Culture Lecturer's Responses

1. Culture is a person's identity and becomes a AL1, AL3, EL1, EL2, differentiator in social strata.

2. Culture is the creation of values and behavior AL2, AL3, EL2, EL3 in the context of social interaction.

\section{Integration Culture in Language Teaching}

1. It is important to instill cultural concepts in AL1, AL2, AL3, EL1, language learners in the classroom

2. The awareness of different cultures among AL3, EL2, EL3 students in the classroom needs to be emphasized and encouraged.

From further interviews, Arabic and English education instructors principally have the same perspective regarding culture. As part of self-identity, language learners and instructors cannot deny the existence of cultural variation between them. Therefore, cultural awareness in the context of language learning in the classroom is needed to acclimate the materials and learning methods to the cultural setting in question. Understanding Arab and English culture helps students and teachers understand how a language should be acquired. The learning objectives that inspire students to speak orally and in writing may be reached optimally. So in this research inquiry, Arabic and English education professors agree that language acquisition cannot be divorced from the culture of the language being spoken. 
What methods and techniques are suitable for teaching language classes with diverse backgrounds?

The six lecturers were asked to write down appropriate learning methods or techniques for language classes with diverse student cultural backgrounds. These results are depicted in the following table:

Tabel 2. Teaching Methods and Techniques

\begin{tabular}{lll} 
No & Teaching Methods & Lecturer's Responses \\
\hline 1 & Participatory Approach & AL3, EL2 \\
\hline 2 & Culture Content Integration & AL1, AL2, EL1, EL2 \\
\hline 3 & Equitable Pedagogy & AL2, AL3, EL1, EL3 \\
\hline 4 & Cooperative Learning & AL1, AL2, AL3, EL1, EL2, \\
& & EL3
\end{tabular}

Basically, the methods used by lecturers in the language learning process in the classroom have so far paid attention to the differences or characteristics of the students themselves. Learning English and Arabic as foreign languages in Indonesia cannot be separated from the origin of the two languages, so learning techniques or methods must be able to adapt to cultural content. Of the four culture-based learning methods, lecturers try to elaborate each method into their language learning classes. This is intended so that students are aware that cultural knowledge is important to understand so that learning content can also run in accordance with the objectives of language learning itself.

What materials or topics are suitable to be taught for these diverse language classes?

In this question section. lecturers are asked to write about material that is suitable for integration in a multicultural language class. From these results, the researchers then tabulated in the following table form:

\section{Tabel 3. Materials/Topics for Language Learning}

\begin{tabular}{lll} 
No & $\begin{array}{c}\text { Material/Topics for Language } \\
\text { Learning }\end{array}$ & \multicolumn{1}{c}{ Lecturer's Responses } \\
\hline 1 & Integration of cultural values. & AL1, AL3, EL1, EL2, EL3 \\
\hline 2 & $\begin{array}{l}\text { Understanding cross-regional } \\
\text { and even national culture }\end{array}$ & AL1, AL2, EL2, EL3 \\
\hline 3 & $\begin{array}{l}\text { Empathy towards cultural } \\
\text { differences }\end{array}$ & $\begin{array}{l}\text { AL1, AL2, AL3, EL1, EL2, } \\
\text { EL3 }\end{array}$ \\
\hline 4 & $\begin{array}{l}\text { Critical understanding of various } \\
\text { cultures in society. }\end{array}$ & AL1, AL2, AL3, EL1, EL2, \\
& EL3 \\
\hline 5 & $\begin{array}{l}\text { Cultural demonstration and } \\
\text { preservation }\end{array}$ & AL1, AL2, EL1, EL3 \\
& &
\end{tabular}


Most of them seem to integrate cultural material in every language learning material. However, in the context of language learning, several lecturers in both English and Arabic chose to integrate cultural values more dominantly than other materials. This is considered important, because the cultural values that are instilled make the material easier to understand if it is related to a certain cultural context. These cultural values are an important emphasis for strengthening language learning materials in the classroom.

\section{How do lecturers increase intercultural awareness in their students?}

Tabel 4. The Way to Increase Intercultural Awareness

No The way to increase intercultural Lecturer's Responses awareness

\begin{tabular}{llll}
\hline 1 & Visualization of cultural content. & AL1, AL2, AL3, EL1, EL3 \\
\hline 2 & $\begin{array}{l}\text { Involvement of social media in } \\
\text { introducing the importance } \\
\text { understanding culture. }\end{array}$ & \\
\hline 3 & $\begin{array}{l}\text { Emphasizing that culture is an } \\
\text { identity that must be maintained }\end{array}$ &
\end{tabular}

Difference and diversity are something natural. Every person, every nation, has its own uniqueness. Even though the world feels like it's getting smaller and smaller, national boundaries due to technological advances, differences and diversity will remain. Many argue that globalization can homogenize existing cultures and there is no need to worry too much about existing cultural differences. Still, the author believes that cultural differences and diversity will definitely exist. Differences and diversity actually add to the splendor of life and are the nation's wealth.

Intercultural awareness and competence in language learners must continue to be maintained and developed. The potential for differences and conflicts in the name of culture can be minimized as early as possible. Intercultural competence must live and become one of the important competencies in every language learner. No more barriers limit students' space and creativity in exploring language skills both inside and outside the classroom. 
Do the reference books used in teaching include intercultural competence so far?

Table 5. Intercultural Competence Integrated to Reference Books Used

\begin{tabular}{lll} 
No & $\begin{array}{c}\text { Intercultural competence integrated to } \\
\text { reference books used in teaching learning }\end{array}$ & Lecture's Responses \\
\hline 1 & $\begin{array}{l}\text { Yes, it was already integrated and considered } \\
\text { intercultural competence in any books used in } \\
\text { teaching language learning in classroom }\end{array}$ & ELL2, EL3 \\
\hline 2 & $\begin{array}{l}\text { Not yet. Intercultural competence has not } \\
\text { been fully integrated into every material or } \\
\text { reference book used in the language learning } \\
\text { process so far. }\end{array}$ \\
\hline $3 \quad \begin{array}{l}\text { Absolutely nothing. Books used as teaching } \\
\text { materials in the classroom do not mention } \\
\text { intercultural competence at all }\end{array}$
\end{tabular}

The Arabic language lecturer stated that the intercultural competence in the various literatures used in the classroom did not fully involve the competence in question. Arabic learning materials are more in contact with the structure and rules of the Arabic language itself. Meanwhile, the English lecturer stated that the language learning materials in the reference books used had taken into account intercultural competence in each material. It's just that English lecturers need more effort to understand these competencies to students.

Is there a reason for lecturers not to teach intercultural competence in language learning in today's class?

\section{Table 6. Reasons for Not Involving Intercultural in Language Learning}

No Reasons for not involving intercultural Lecturer's Responses competence in language learning

There is no reason not to integrate All respondents agreed intercultural competence in language learning today.

Learning a foreign language entails more than just learning linguistic characteristics and developing the four language skills (listening, speaking, reading, and writing); it also necessitates an awareness of the country's culture in which the language is being studied. Experts suggest that a higher emphasis should be placed on developing the ability to communicate in the target language when this culture is introduced, particularly in language learning environments. It has been shown that including cultural elements in the process of learning a foreign language can help to lessen the likelihood of misunderstandings occurring during the ongoing communication process. 
How have students reacted so far in understanding culture in the context of the language material being taught?

Table 7. Students' React in Understanding Culture

No Students' react in understanding Lecturers' Responses culture

1 Promoting language learning based on AL1, AL2, AL3, EL1, EL2, intercultural competence is important EL3 because it can foster a humanistic tolerance.

2 Language learning that is integrated AL1, AL3, EL2 with cultural competence has not been maximized and there is no student awareness.

3 Students think that language learning All Respondents stated the does not need to be integrated with culture because language and culture are different things.

students has a positive
perspective of the relation between language and culture

Student awareness of the importance of mastering current cultural competence shows a positive thing. The experience of the six lecturers stated that the students strongly agreed that language learning should always be linked to culture, because culture and language are a package that cannot be separated from each other. Learning English and Arabic cannot be separated from where the language was born, so learning English and Arabic should not only focus on aspects of the language as a whole, but it is important to combine knowledge of the culture where the language was born so that there is no misconception of terms in the two languages.

\section{Discussion}

The fundamental goal of language education and learning is to speak a foreign language with confidence. It should be noted that communication is not only a subject of language and vocabulary; it is also an issue of culture (Lustig, Myron W, 2010). Every communication a human being expresses through language is communicated in the context of a particular cultural tradition (King et al., 2013). It is cultures that influence how language is constructed as well as the ways in which language is used (Jackson, 2019). A language learner who has simply learned the grammar and vocabulary of a language is, as a result, ill-prepared to communicate effectively in that particular language (Dagbaeva et al., 2020). When people begin to transmit messages in a foreign language, they not only start to exploit the language's functions, but they also begin to act within the cultural environment in which they are communicating. As a result, learners require 
cultural understanding as much as they do grammatical and vocabulary knowledge. Most of the time, native speakers are tolerant of grammatical or vocabulary errors. Still, problems of cultural mismatch frequently cause significant communication and social relationship difficulties, largely because people are much less aware of their cultural rules for interaction than they are of other aspects of language.

Cultural knowledge cannot be taught or learned in a classroom setting. In fact, cultural differences may often go unnoticed by learners until they become a source of contention (Dalib et al., 2019; de Hei et al., 2020; Peng et al., 2020). Learners need to be assisted in recognizing when their culture differs from others' for them to realize this before it leads to problems. This is where language teachers must employ explicit instruction to call their students' attention to culture and the various ways in which different cultures function.

Intercultural Competence (IC) has been promoted due to the current trend in language education (particularly foreign languages), which emphasizes the development of communicative language abilities. This has prompted language teachers to develop intercultural competence (IC) in their students. Because humans, in general, carry out cultural behaviors, particularly through language, IC becomes a significant factor in their lives. When it comes to cross-language communication, intercultural communication (IC) serves as a link between the culture of the language learner and the culture of the target language being studied. The meaning of the IC idea can be found in various contexts.

(Lustig, Myron W, 2010) asserts that whenever we utilize language and culture simultaneously, we are engaging in cultural practice. When interculturally competent, you feel like you are in the "third place." This "third place" can be compared to a place (or rather a position) where language learners can act as both a "outsider" and a "insider" at the same time, gaining a "etic" perspective (as an outsider) as well as a "emic" perspective (as an insider) on their own culture as well as the culture of the language they are learning.

When language learners are able to improve cultural sensitivity, IC manifests itself as a shift from "viewing reality simply from the point of view of their own culture" to "realizing that there are many other points of view in this world." In connection with this, Bennet, Bennet, and (Lieberman \& Gamst, 2015) claim that intercultural competence (IC) 
is the ability to evolve from a "ethnocentric" perspective to an attitude of respect for other cultures, eventually leading to the ability to behave correctly in a culture or cultures.

\section{CONCLUSION}

In foreign language teaching and learning, it appears that knowledge of culture is essential. On the other hand, teachers should have proper training on how to deal with cultural difficulties and how to include cultural elements into their teaching practices. It is feasible to deduce from the data collected through the interviews that all of the instructors recognize the need to integrate culture into FL classrooms through the use of various strategies and resources. Their statements include the following: most of the time. They are required to stick to textbook activities and activities in the already prepared textbook since they have minimal time to deal with cultural issues in class due to the excessive demands of the syllabi.

Consequently, in addition to the linguistic component, a more complex cultural component with carefully crafted teaching methods and procedures should be incorporated into the FLT curriculum for it to be taught in an integrated manner. This component is also critical in assisting learners in increasing their cultural awareness, embracing feelings such as empathy and tolerance, demonstrating respect for other cultures, broadening their perspectives, and appreciating the similarities and differences between different cultures. To put it another way, intercultural activities and courses must be accorded the same prominence in the curriculum as the other language-related activities.

\section{REFERENCES}

Barnatt, J., Andries D’Souza, L., Gleeson, A. M., Mitchell Viesca, K., \& Wery, J. (2020). Intercultural competence in pre-service teacher candidates. International Journal of Educational Reform, 29(3). https://doi.org/10.1177/1056787919896866

Behrnd, V., \& Porzelt, S. (2012). Intercultural competence and training outcomes of students with experiences abroad. International Journal of Intercultural Relations, 36(2). https://doi.org/10.1016/j.ijintrel.2011.04.005

Bennett, J. (2009). Cultivating intercultural competence. The Sage Handbook of Intercultural Competence.

Burden, J. W., Columna, L., Hodge, S. R., \& Martínez de la Vega Mansilla, P. (2013). Ethnolinguistically relevant pedagogy: Empowering English language learners in physical education. Quest, 65(2). https://doi.org/10.1080/00336297.2013.773528 
Byram, M. (2020). Teaching and assessing intercultural communicative competence. In Teaching and Assessing Intercultural Communicative Competence. https://doi.org/10.21832/byram0244

Dagbaeva, N. Z., Darmaeva, S. N., Samoshkina, J. S., \& Tzybenova, S. G. (2020). Components of modern students' intercultural competence: Comparative analysis. European Journal of Contemporary Education, 9(1). https://doi.org/10.13187/ejced.2020.1.19

Dalib, S., Harun, M., Yusof, N., \& Ahmad, M. K. (2019). Exploring intercultural competence among students in Malaysian campuses. Jurnal Komunikasi: Malaysian Journal of Communication, 35(1). https://doi.org/10.17576/JKMJC-2019-3501-01

de Hei, M., Tabacaru, C., Sjoer, E., Rippe, R., \& Walenkamp, J. (2020). Developing intercultural competence through collaborative learning in international higher education. Journal of Studies in International Education, 24(2). https://doi.org/10.1177/1028315319826226

Ferreira-Lopes, L., Bezanilla, M. J., \& Elexpuru, I. (2018). Integrating intercultural competence development into the curriculum through telecollaboration. A task sequence proposal for higher education. Revista de Educacion a Distancia, 58. https://doi.org/10.6018/red/58/7

Gómez-Parra, M. E. (2020). Measuring intercultural learning through CLIL. Journal of New Approaches in Educational Research, 9(1). https://doi.org/10.7821/naer.2020.1.457

Hashemian, M., \& Farhang-Ju, M. (2020). Relationship between Iranian L2 learners' intercultural communicative competence and personality traits. Khazar Journal of Humanities and Social Sciences, 23(1). https://doi.org/10.5782/22232621.2020.23.1.69

Holmes, P., \& O'Neill, G. (2012). Developing and evaluating intercultural competence: Ethnographies of intercultural encounters. International Journal of Intercultural Relations, 36(5). https://doi.org/10.1016/j.ijintrel.2012.04.010

Ihm, H.-J. (2020). An analysis of content and language integrated English course book. Korean Association For Learner-Centered Curriculum And Instruction, 20(2). https://doi.org/10.22251/jlcci.2020.20.2.947

Jackson, J. (2019). Intercultural competence and L2 pragmatics. In The Routledge Handbook of Second Language Acquisition and Pragmatics. https://doi.org/10.4324/9781351164085-31

King, P. M., Perez, R. J., \& Shim, W. J. (2013). How college students experience intercultural learning: Key features and approaches. Journal of Diversity in Higher Education, 6(2). https://doi.org/10.1037/a0033243

Lieberman, D. A., \& Gamst, G. (2015). Intercultural communication competence revisited: Linking the intercultural and multicultural fields. International Journal of Intercultural Relations, 48. https://doi.org/10.1016/j.ijintrel.2015.03.007

Lustig, Myron W, J. K. (2010). Intercultural competence: Interpersonal communication across cultures.

Maharaja, G. (2018). The impact of study abroad on college students' intercultural competence and personal development. International Research and Review: Journal of Phi Beta Delta Honor Society for International Scholars, 7(2).

Mirzaei, A., \& Forouzandeh, F. (2013). Relationship between intercultural communicative competence and 12-learning motivation of Iranian EFL learners. 
Journal of Intercultural Communication Research, 42(3). https://doi.org/10.1080/17475759.2013.816867

Peng, R. Z., Zhu, C., \& Wu, W. P. (2020). Visualizing the knowledge domain of intercultural competence research: A bibliometric analysis. International Journal of Intercultural Relations, 74. https://doi.org/10.1016/j.ijintrel.2019.10.008

Pinto, S. (2018). Intercultural competence in higher education: academics' perspectives. On the Horizon, 26(2). https://doi.org/10.1108/OTH-02-2018-0011

Ridder, H. G., Miles, M. B., Michael Huberman, A., \& Saldaña, J. (2014). Qualitative data analysis. A methods sourcebook. Zeitschrift Fur Personalforschung. https://doi.org/10.1177/239700221402800402

Róg, T., Moros-Pałys, Z., Wróbel, A., \& Książek-Róg, M. (2020). Intercultural competence and 12 acquisition in the study abroad context. Journal of Intercultural Communication, 2020(52).

Sevilla-Pavón, A. (2019). L1 versus L2 online intercultural exchanges for the development of 21 st century competences: The students' perspective. British Journal of Educational Technology, 50(2). https://doi.org/10.1111/bjet.12602

Shadiev, R., Xueying, W., \& Huang, Y. M. (2020). Promoting Intercultural competence in a learning activity supported by virtual reality technology. International Review of Research in Open and Distance Learning, 21(3). https://doi.org/10.19173/irrodl.v21i3.4752

Vuksanovic, J. (2018). ESL learners' intercultural competence, L2 attitudes and WEB 2.0 use in American culture. Journal of Intercultural Communication, 2018(46).

Wang, H. C. (2020). Facilitating English L2 learners' intercultural competence and learning of English in a Taiwanese university. Language Teaching Research. https://doi.org/10.1177/1362168820969359

Wolff, F., \& Borzikowsky, C. (2018). Intercultural competence by international experiences? An investigation of the impact of educational stays abroad on intercultural competence and its facets. Journal of Cross-Cultural Psychology, 49(3). https://doi.org/10.1177/0022022118754721

Wyant, J. D., Killick, L., \& Bowen, K. (2019). Intercultural competence: Physical education teacher education recommendations. Quest, 71(4). https://doi.org/10.1080/00336297.2018.1542320 